\title{
Developing Criteria of an English Textbook Evaluation for Indonesian Senior High School
}

Received: 13-09-2021; Revised: 11-11-2021; Accepted: 6-12-2021

\section{Sirajul Munir*)}

Institut Agama Islam Negeri Batusangkar, West Sumatera, Indonesia

E-mail

sirajulmunir@iainbatusangkar.ac.id

\section{Nina Suzanne}

Institut Agama Islam Negeri Batusangkar, West Sumatera, Indonesia

E-mail:

ninasuzanne@iainbatusangkar.ac.id

\section{Yulnetri}

Institut Agama Islam Negeri Batusangkar, West Sumatera, Indonesia

E-mail: yulnetri@iainbatusangkar.ac.id

*) Corresponding Author
Abstract: The use of criteria of an English textbook is crucial to improve the quality of teaching. However, choosing the criteria is a challenging task for teachers and material developers. This recent study aims at developing criteria of an English textbook evaluation for Indonesian Senior High School. This research used Research and Development. Three phases were employed: exploration stage, development stage, and validation stage. At the exploration stage, 17 respondents of English teachers were asked about the need of developing the criteria of the English textbook. All respondents agreed that the textbook evaluation criteria were needed since there is no particular standardized textbook evaluation available. Therefore, they need to use the criteria as the basis to determine the quality of a particular textbook. At the development stage, 10 criteria to evaluate textbooks were constructed. Those cover (1) aims and approaches; (2) design and organization; (3); content; (4) skills; (5) vocabulary; (6) exercises and activities; (7) methodology; (8) attractiveness of the textbook and physical make-up; (9) teacher's manual; and (10) practical consideration. At the validation stage, the textbook evaluation criteria were deemed valid by experts. Considering these facts, 10 designed criteria could be used as the principle to determine an evaluation of English textbooks, primarily in the teaching English at Indonesian Senior High school.

Abstrak: Penggunaan kriteria buku teks bahasa Inggris sangat penting untuk meningkatkan kualitas pengajaran. Namun, memilih kriteria adalah tugas yang menantang bagi guru dan pengembang materi. Penelitian terbaru ini bertujuan untuk mengembangkan kriteria evaluasi buku teks Bahasa Inggris untuk Sekolah Menengah Atas Bahasa Indonesia. Penelitian ini menggunakan Research and Development. Tiga fase digunakan: tahap eksplorasi, tahap pengembangan, dan tahap validasi. Pada tahap eksplorasi, 17 responden guru bahasa Inggris ditanya tentang perlunya mengembangkan kriteria buku teks bahasa Inggris. Semua responden setuju bahwa kriteria evaluasi buku teks diperlukan karena tidak ada standar evaluasi buku teks tertentu yang tersedia. Oleh karena itu, mereka perlu menggunakan kriteria sebagai dasar untuk menentukan kualitas buku teks tertentu. Pada tahap pengembangan, dibangun 10 kriteria untuk mengevaluasi buku teks. Hal tersebut meliputi (1) tujuan dan pendekatan; (2) desain dan organisasi; (3); isi; (4) keterampilan; (5) kosakata; (6) latihan dan aktivitas; (7) 
metodologi; (8) daya tarik buku teks dan rias fisik; (9) buku pedoman guru; dan (10) pertimbangan praktis. Pada tahap validasi, kriteria evaluasi buku teks dianggap valid oleh para ahli. Dengan mempertimbangkan fakta tersebut, 10 kriteria yang dirancang dapat digunakan sebagai prinsip untuk menentukan evaluasi buku teks bahasa Inggris, terutama dalam pengajaran bahasa Inggris di Sekolah Menengah Atas Indonesia.

Keywords: Criteria, English textbook, Senior High School

\section{INTRODUCTION}

$\mathrm{N}$ o one can disagree that textbook becomes the key component to determine the language learning success. Okeeffe (2013) highlights that a textbook plays the essential role to promote curricula. Similarly, Mukundun \& Nimenhchisalem (2012) postulates that textbook is considered the next important element in ELT leaning. Besharati \& Mazdayasna (2017) assert that textbooks are the pivotal role in making decision and judgment. Gebregeorgis (2017) concedes that textbooks are not only to provide subject knowledge but also to community specific values.

Teachers have an important role in choosing the appropriate textbooks for the students in order to gain the success at learning. To choose the certain textbook, there should be criteria in order to meet the students' needs. Prior research demonstrates that English teachers often find difficulties in determining the criteria of a good English textbook. Although numerous researches Cunninsworth (1995); Litz (2005); Jagahard (2007); Alamri (2008); and Munir (2013) have shown criteria of a good textbook from different points of view, there is a need to explore further investigation, particularly in the context of Indonesian Senior high school levels. Cunningsworth (1995) Highlights the criteria of a good textbook as follows (1) aims and approach (2) design and organization, (3) language content (4) skills, (5) topic, (6) methodology, (7) teacher's book logy, (8) practical consideration. Furthermore, Alamri (2008) elaborated the more detail criteria. He adds other criteria including language, topic, social, and cultural content, flexibility, and teachability, and testing. (Litz, 2005) suggests a set of criteria as follows: (1) practical consideration, (2) layout and design, (3) activities, (4) skills, (5) language type, (6) subject and content, (7) conclusion/ overall activities. Jahangard (2007) presents a criteria of a textbook, namely (1) explicit objectives in the layout in an introduction, and implemented in the material, (2) good vocabulary explanation and practice, (3) approaches educationally and socially accepted to target community, (4) periodic review and test sections, (5) appropriate visual materials available, (6) interesting topics and tasks, (7) clear instructions, (8) clear attractive layout, print easy to read, (9)content clearly organized and graded, (10) plenty of automatic language, (11) good grammar presentation and practice, (12) fluency practice in all four skills, (13) encourage learners to develop own learning strategies and to become independent in their language. Finally, Munir (2013) made the textbook criteria in the field of reading comprehension.

Based on the preliminary observation and interviews conducted with English teachers, finding appropriate criteria of an English textbook evaluation is one of the major problems for them. Although there are some related criteria for evaluating textbooks, they are not satisfactory yet. The present criteria are not precise and practical to be used. The criteria suggested by some experts are addressed to evaluate textbooks in general. Whereas they need specific criteria intended to evaluate English textbooks for high school students. Furthermore, the layout and the organization of the criteria seem complicated for them. It, therefore, suggests educators and material developers provide the 
appropriate criteria in order English teachers could use them as the basis to determine the quality of a particular textbook.

In recent times, millions of English textbooks are provided for English teachers at Senior High Schools. They can get many textbooks offline or online. Nevertheless, very little is written on the subject of how to determine the quality of the textbooks using certain criteria. Cunningsworth (1995), Richards (1998), Miekley (2005), and Munir, (2013) highlight using criteria to determine the quality of the textbook. This is a way to guide the qualified and appropriate textbook to use. However, as it is explained above, the existed criteria should be developed based on teachers' needs in terms of the items or indicators, layout, categories, organization, and also procedures. The main focus of this research is to develop the features updates of the criteria of an English textbook evaluation in the context of Indonesian senior high school.

\section{METHOD}

This study used The Research and Development ( $R$ \&D) approach since the objective of this study is to develop criteria of an English textbook evaluation. Three phases as suggested by Sukmadinata (2008) were employed, namely: exploration phase, development phase, and validation phase. At the exploration phase, the researchers interviewed 17 Senior High School English teachers on the need to develop the criteria. These 17 English teachers were selected through purposive sampling. There were (1) English teachers at Senior High School; (2) have more than 10 years of teaching English Experience; (3) have learned crtiteria of a good English textbook. All informants agreed to develop the criteria of the textbook.

In the development phase, the researchers made 10 criteria. The criteria were developed based on interview results. The criteria basically were adapted and modified from the previous ELT prominent. Last, at the validation phase, researchers employed experts' validation. Three experts judged the criteria. The results show that the criteria made were valid.

\section{RESULTS AND DISCUSSION \\ Results}

\section{Exploration Phase (The Present Criteria of an English Textbook Evaluation)}

Based on the document analysis on the existing criteria of textbook evaluation, the researchers found that there is no standard criterion used by the English teachers of senior high schools in deciding the good textbook used in their class. Generally, the teachers chose one or more books that provide some topics or materials described in the syllabus. Therefore, to make a criterion of a textbook evaluation in the context of Senior High School is deemed crucial in the process of teaching and learning English. In addition to this, what to be evaluated and how to evaluate become two concepts that should be discussed seriously. Moreover, the result of the interview with 17 Senior High School English teachers indicated that they need particular criteria for the textbook evaluation.

Every teacher should not have his/her own criteria. It is much better that all English teachers of senior high school do evaluation under the same criteria. As a matter of fact, there is no absolute criteria for textbook evaluation because teachers and students may face a different situation in their classroom. However, having the right criteria is crucial for the English teachers. They even can add others of their own based on their concerns and priorities.

\section{Development Phase}

The criteria of an English textbook evaluation that is developed in this research basically used the idea of Cunningsworth (1995), sworth (1995), Richard (1998), Miekley (2005), and Munir (2013). The researchers, then combined and modified as a guidance for English teachers of Senior High Schools 
to use appropriate textbooks for their students. The criteria of English textbook evaluation is written in an evaluation rubric. The rubric consists of 10 indicators with 55 statements and also rating scale that is divided into excellent (4), good (3), fair (2) and poor (1). The criteria are as follows:

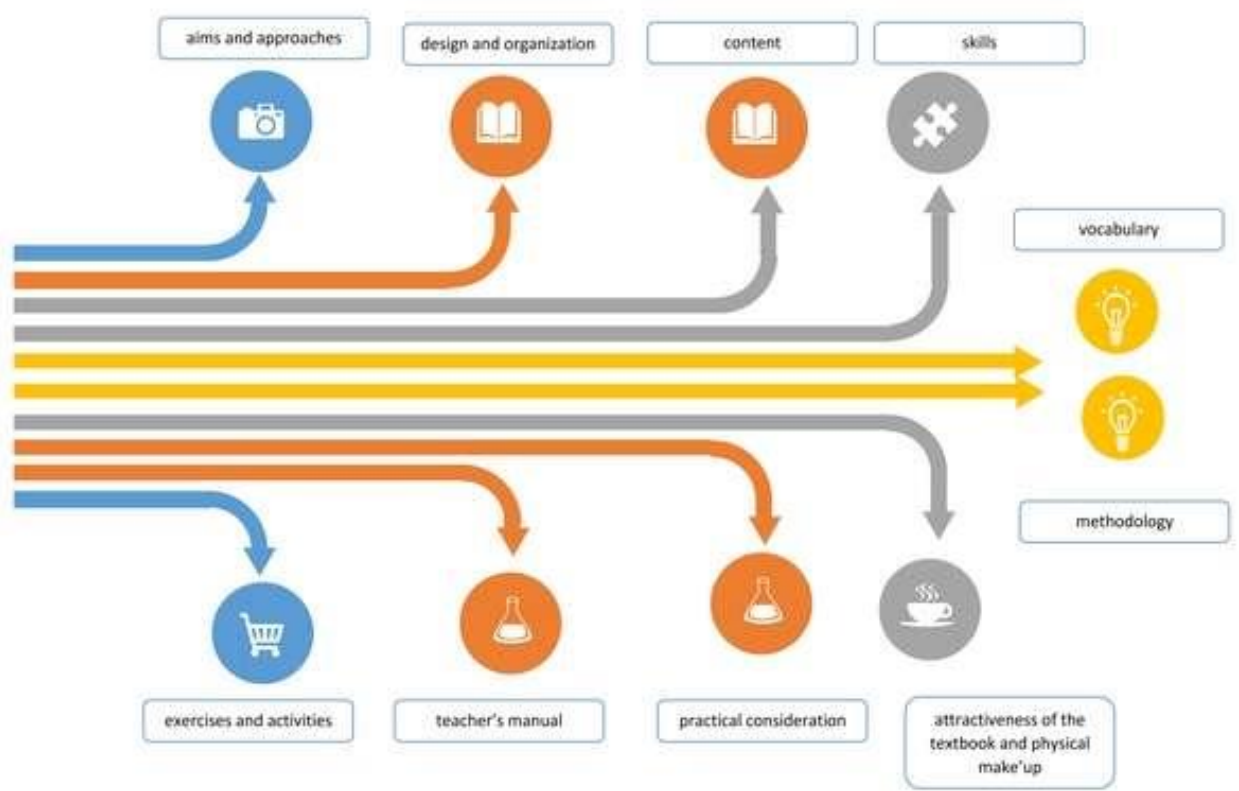

Figure 1: Criteria of an English Textbook

More detail information on the criteria are

elaborated in the following section:

\section{Aims and Approaches}

This criterion is very important because the

Aims and approaches are the first criteria teachers are expected to know well to whom to be considered in choosing the appropriate the materials will be used (for the students textbooks. Teachers should identify the aims and the teachers themselves) and give special and objectives of their teaching programs and attention on their need. Seven sub-indicators also analyze the learning and teaching or statements become the main focus on these situation in which the material will be used. first criteria, they are:

Table 1. Aims and Approaches

Textbook Title :
Author(s) :
Publisher :
Year of Publication:

Aims and Approaches

1. The objectives of textbook are quite similar to the curriculum's objectives.

2. The textbook's objectives meet the needs of learners.

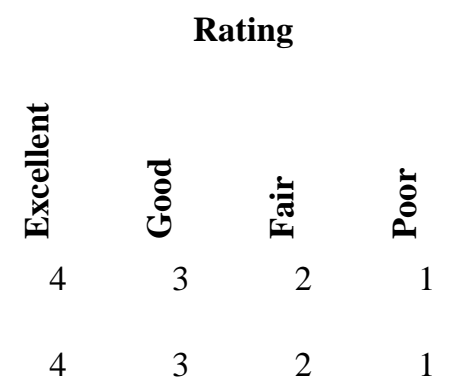


3. The textbook is appropriate for both learning and teaching.

4. The textbook mainly consists of what is required.

5. For the students, a textbook is an excellent resource.

6. For the teachers, a textbook is an excellent resource.

7. Different teaching and learning methods are accommodated by the textbook.

\section{Design and Organization}

The design and organization of a textbook deals with the layout, supported equipment and tools, workbook, the organization of content, and also the grading. The organization of textbooks describes the amount of continuity within the materials and the routes through the materials which are available to learners. The rubric can be seen as follows:

Table 2. Design and Organization

\section{Design and Organization}

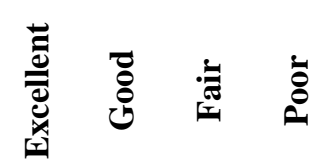

1. The textbook includes a complete course package (e.g., teachers' $\quad \begin{array}{llll}4 & 3 & 2 & 1\end{array}$ books, students' books, cassettes, workbooks)

2. The content is well-organized. (e.g., based on structures, topics, $\begin{array}{lllll}4 & 3 & 2 & 1\end{array}$ functions, skills, etc.)

3. The content is organized (e.g., by complexity, "learnability," $\quad \begin{array}{lllll}4 & 3 & 2 & 1\end{array}$ usefulness, and so on).

4. The grading and progression are appropriate for the learners. $\quad \begin{array}{lllll}4 & 3 & 2 & 1\end{array}$

5. The layout is easy to understand.

\section{Content}

Content deals with what topics textbooks have, the subject matter they select and how they treat it. In addition, the content of a textbook should also reflect the cultural settings includes the image of life presented by a textbook, the attitude it conveys, consciously or unconsciously, and the values of social and culture that they communicate. A language textbook of course should be a mean for facilitating language learning (skills, components, linguistic, etc). This criteria has 9 sub-indicators which can be presented below.

Table 3. Content

\section{Content}

1. The reading selections are authentic language components.

2. The audio contains authentic language components.

3. The situation for speaking activities is based on a real-life situation.

4. The text writing features genres of writing.

5. The text selections represents a lot of literary styles.

6. The content is suitable (interesting, challenging, topical, varied, culturally acceptable, unlike to date)

7. There is enough variety and number of topics

8. The topics engage students increase their knowledge and deepen their experience.

9. The social and cultural contexts described in the textbook will be relatable to students. 


\section{Skills}

The four skills in English language are deemed as very crucial in language learning. Consequently, one cannot ignore the linguistic behaviour. Textbook developers can make in isolation, others can use integrated skills. A good textbook also provides the knowledge of grammar, lexis, and the four skills should develop the skills of students in the use of fluent English as well as their knowledge about the language. The main indicators in the developed criteria of textbook evaluation can be viewed as follows.

Table 4. Skills

Skills

1. The reading texts are used to introduce new language items (grammar and vocabulary), consolidate language learning, and so on.

2. The development of four language skills is prioritized (speaking, listening, $\quad \begin{array}{lllll}4 & 3 & 2 & 1\end{array}$ reading, and writing)

3. The development of listening, speaking, reading, and writing strategies is $\begin{array}{lllll}4 & 3 & 2 & 1\end{array}$ prioritized.

4. The reading materials that are linked to other skills work.

5. Intensive and extended activities are encouraged by the skills.

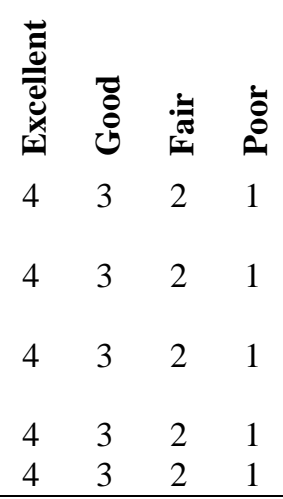

\section{Vocabulary}

Vocabulary is often not seen as a very important aspect in foreign language teaching. In fact, it is impossible for students to build communication effectively without the knowledge of vocabulary. For this reason, a good textbook should provide vocabulary based on a process of selection that involved a particular criterion, such as the frequency of the use of the vocabulary, the complexity, etc. The Vocabulary area can be noticed below.

Table 5. Vocabulary

\section{Vocabulary}

\begin{tabular}{|c|c|c|c|}
\hline 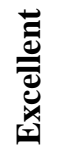 & 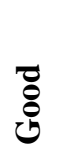 & 弍 & $\stackrel{\check{8}}{0}$ \\
\hline 4 & 3 & 2 & 1 \\
\hline 4 & 3 & 2 & 1 \\
\hline 4 & 3 & 2 & 1 \\
\hline 4 & 3 & 2 & 1 \\
\hline
\end{tabular}

\section{Exercises and Activities}

A good textbook provides its users with some tasks and activities that are important to determine their progress and achievement after a single topic or theme. The tasks and activities should be able to facilitate the classroom language activities. These criteria are as follows. 
Table 6. Exercises and Activities

\title{
Exercises and Activities
}

1. The textbook contains interactive and task-based activities that require students to communicate using new language.

2. The textbook instructs students to listen and read for understanding.

3. Instructions in the textbook tell students to produce English in a communicative manner.

4. Top-down and bottom-up reading techniques are utilized.

5. Students are provided enough examples to develop top-down technique for reading comprehension.

6. The books make understanding easier by addressing one new concept at a time rather than several new concepts,

7. The exercises encourage to think critically about the text.

8. Intensive and extensive activities are assigned to the students.

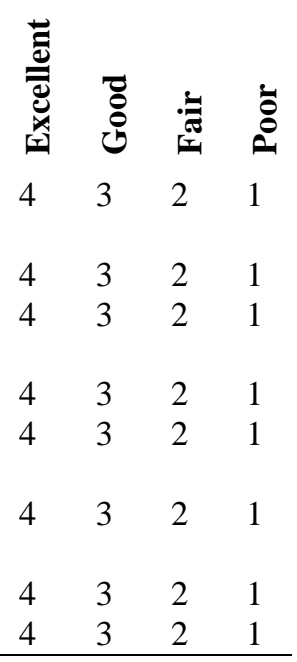

\section{Methodology}

A good textbook promotes how the learners learn the language and how the textbook is taught clearly. The methodology of a textbook can describe how it sees the learning process, how it analyses the needs and roles of learners, and how it can help learners to learn. The sub-indicators of this criteria can be presented as follows.

Table 7. Methodology

\section{Methodology}

1. The textbook presents a method for learning a language.

2. The textbook is suited to the learning styles and expectations of the students.

3. The techniques for introducing and practicing new language items are appropriate for your students.

4. The variety skills are taught

5. The ability to communicate is developed.

6. Before moving on to new topics, teachers engage students' background $\begin{array}{lllll}4 & 3 & 2 & 1\end{array}$ knowledge.

\begin{abstract}
Attractiveness of the Textbook and connected and supported each other. For Physical make-Up

example, the use of a workbook and cassette

A textbook is a whole learning package that can not stand alone. One aspect and another are connected. It is important to find can work together to form an integrated package. This indicator can be observed in more detail in the table.
\end{abstract}


Table 8. Attractiveness of the Textbook and Physical Make-up

\section{Attractiveness of the Textbook and Physical Make-Up}

1. The textbook's cover is attractive.

2. The visual imagery in the textbook have outstanding aesthetic level.

3. The illustrations are simple enough and relatively close to the text to enhance rather than distract from its meaning.

4. The text is interesting enough which make the students will happy to read it

\begin{tabular}{|c|c|c|c|}
\hline 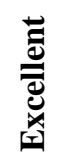 & '̊ & 丞 & $\ddot{\Xi}$ \\
\hline 4 & 3 & 2 & 1 \\
\hline 4 & 3 & 2 & 1 \\
\hline 4 & 3 & 2 & 1 \\
\hline 4 & 3 & 2 & 1 \\
\hline
\end{tabular}

\section{Teacher's Manual}

Teachers have an important role in the use of textbooks and make the teaching and learning process run well and smoothly. Teachers should feel free to make changes while using the textbook where they feel it to be necessary and in the student's interest.
Especially for new and inexperienced teachers, manual or guidance in using the textbook is very crucial. It will help them lead the learning process, monitor it, and correct errors if any. The following table shows the statements for the teacher's manual.

Table 9. Teacher's Manual

\section{Teacher's Manual}

1. There is sufficient direction for the teachers who will be using the textbook and its supplementary materials.

2. For the activities in the textbook, correct suggested answers are provided.

3. Teaching approaches, linguistic issues such as grammatical rules and vocabulary, and culture-specific information are all effectively covered in the textbook.

\section{Practical Considerations}

It is widely accepted that there is no single textbook will ever be perfect for a language program. One book may be practical for one language course but cannot be used for another one. Teachers should not have to spend much time working out how to use the material. Besides, materials should require and facilitate learner self-investment. The statement used for these indicators are described in the following table.

Table 10. Practical Considerations

\section{Practical Considerations}

1. The total package cost provides excellent value for money.

2. The book is long-lasting and durable.

3. The textbook has an attractive design.

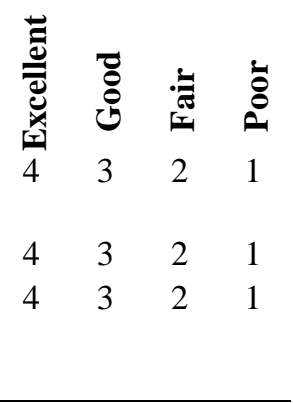

\section{Table 10. Practical Considerations}


To make it easy to evaluate the quality of textbooks, the researchers provide a four rating scales. They include excellent, good, fair, dan poor. The descriptor of each rating scale is presented below:

Table 11. Rating Scale and Its Interpretation

\begin{tabular}{ccl}
\hline Score & Rating & \multicolumn{1}{c}{ Descriptor } \\
\hline 4 & Excellent & $\begin{array}{l}\text { A textbook is considered good if it has a lot of strong points and just few } \\
\text { weaknesses. }\end{array}$ \\
3 & Good & $\begin{array}{l}\text { A textbook is considered good if it has solid but with just few weaknesses } \\
\text { A textbook is deemed textbook if it has few strengths and a lot of } \\
\text { weaknesses } \\
\text { A textbook is considered poor textbook if it has very minor strengths and so } \\
\text { many major weaknesses }\end{array}$ \\
\hline
\end{tabular}

\section{Validation Phase}

To validate these criteria, three experts were involved. The experts concerned on both content and construct of the prototype. In general, all experts concluded that the criteria of textbook evaluation which has been developed based on the need analysis result is accepted. As a result, it can be used to choose the appropriate textbooks for English language classroom, especially for senior high school students.

The validation of the criteria of textbook evaluation was focused on four aspects. (1) the relevance to its indicators. 53 statements are highly valid and only two statements are less valid; (2) the relevance to the purpose of criteria development. The 55 statements in the criteria are arranged and developed to achieve the purposes. Experts judgement indicate that most of the statements are highly valid and only two statements (No 9 and 10) which are less valid; (3) the readability and clarity. 46 statements are highly valid, 2 statements are less valid, and 7 statements are valid; and (4) the language used. There are 13 statements are considered less valid. The researchers are supposed to not consistent in using the tense: simple present and past tense, active and passive voice, the choice of words, etc. In conclusion, the language used in the criteria is quite complicated and should be simplified and clear.

\section{Discussion}

The research finding indicates that English teachers at Senior High Schools need the criteria for textbook evaluation to improve the quality of teaching. This idea confirms the previous research by Roberts et al. (2020) who state that researchers need to explore the criteria of EFL textbooks to assist teachers in enhancing the quality of teaching process and procedures. In addition, Gholami et al. (2017) have emphasized that developing the textbook evaluation becomes a mandatory process by language experts. Similarly, Nursyahrifa et al (2019) report that developing a textbook evaluation is essential to achieve curriculum objectives.

The findings of this present study show similarities and differences criteria proposed by previous prominent ELT experts. The similarity could be seen in ten criteria as highlighted by Cunningsworth (1995), Richard (1998), Miekley (2005), and Nimenhchisalem (2012). The similarities lie in general criteria such as aims and approaches, design and organization, content, skills, vocabulary, exercises and activities, methodology, attractiveness of the textbook and physical make-up, teacher's manual, and practical consideration.

The differences, however, include some features of each indicator as well as statement development. The previous researchers demonstrate the absence of standard criteria of textbook evaluation. Hence, the criteria were limited indicators 
and statements. This study, however, adds and enlarges detailed criteria. Furthermore, the evaluation rubric is seen as different. While Cunningswoth (1995) highlights 9 criteria for evaluating English textbook, this research enlarges the indicators become 10 main indicators and further add some more statements for each indicator. Then, as Alamri (2008) provides a set of criteria into 12 indicators, the researchers simplify them into the 10 criteria.

Another interesting finding here is while several ELT experts (Cuningswoth, 1995; Harmer, 2001 and Richard, 1999) only gave a criterion, they did not provide a certain rating scale for the evaluating the English textbook. This study, however, designs the system of rating based on a 4- point scale, namely excellent (4), good (3), fair (2), and poor (1). In addition to this, the researchers propose the descriptor of each rating scale. Furthermore, the standard criteria of a textbook are designed to easy to follow and more objective evaluation. Each aspect has clear and brief indicators and supported by simple but exact quality scale. At the end of the process, there is also a guide to calculate and interpret the evaluation result quantitatively and qualitatively. This is in pertinent with Karamoozian \& Riazi (2008) who advocate to use easy format and simple checklists in order teachers can use them easily and friendly.

\section{CONCLUSION}

This study concludes that some English teachers in senior high schools need a criteria for English textbook evaluation. They can use and decide the appropriate textbooks for their students. The criteria of textbook evaluation include ten indicators, namely (a) aims and approaches; (b) design and organization; (c) content; (d) skills; (e) vocabulary; (f) exercises and activities; (g) methodology; (h) attractiveness of the textbook and physical make-up; (i) teacher's manual; and (j) practical consideration. The result of experts' validation indicate that the criteria are valid and can be used by English teachers to evaluate the quality of an English textbook. Because of some limitations in doing this research, this research just came to the end after expert validation. It is encouraged that the next researchers do the next steps such as doing its practicality. Having discussion with some teachers also necessary to identify their difficulty and their impression to use this criterion. Last but not least, it is suggested to other researchers to investigate more specific area such as in listening comprehension, reading comprehension, speaking, and writing.

\section{REFERENCES}

Alamri, A. A. M. (2008). An Evaluation of the Six Grade English Language Textbook for Saudi Boy's Schools. Unpublished M.A Thesis. King Saud University.

Besharati, M. H., \& Mazdayasna, G. (2017). Investigating Iranian EFL students' attitudes concerning the newly developed ESP materials. Modern Journal of Language Teaching Methods, 7(5), 45-58.

Cunningsworth, A. (1995). Choosing Your Coursebook. Oxford: Heinemann Publishers Ltd.

Gebregeorgis, M. Y. (2017). Peace Values in Language Textbooks: the case of English for Ethopia Students Textbook. Journal of Peace Education, 14(1), 5468.

Gholami, R., Noodin, N., \& Rafik-Galea., S. (2017). A Through Scrutiny of ELT Textbook Evaluation: A Review Inquiry. International Journal of Education \& Literacy Studies, 5(3), 8291.

Harmer, J. (2001). The Practice of English Language Teaching. Essex: Pearson Education Limited.

Jahangard, A. (2007). Evaluation of EFL Materials Taught at Iranian Public High Schools. The Asian EFL Journal, 9(2), 169.

Karamoozian, \& Riazi, A. (2008). Development of a New Checklist for Evaluating Reading Comprehension Textbooks. ESP World 3 (19), 7. 
http://www.esp-world.info.

Litz, D. R. A. (2005). Textbook Evaluation and ELT Management: A South Korean Case Study. Asian EFL Journal. http://www.asian-efljournal.com/Litz_thesis.pdf.\%0A

Miekley, J. (2005). ESL Textbook Evaluation Checklist. The Reading Matrix. The Reading Matrix, 5(2).

Mukundun, J., \& Nimenhchisalem, V. (2012). Evaluative Criteria of an English Language Textbook Evaluation Checklist. Journal of Language Teaching and Research, 3(6), 11281134.

Munir, S. (2013). Developing a Checklist for Evaluating Reading Comprehension Textbook. Seminar Nasional Evaluasi Pendidikan Universitas Negeri
Semarang, 139-149.

Okeeffe, L. (2013). A Framework for Textbook Analysis. International Review of Contemporary Learning Research, 2(1), 1-13.

Richards, J. C. (1998). Beyond Training: Perspectives on Language Teacher Education. Cambridge: Cambridge University Press.

Roberts, F., Aziz, A., \& Matore, E. (2020). Criteria of a Good ELT Textbook: Malaysian Teachers' Perception. Universal Journal of Education Research, 8(12A), 7433-7442.

Sukmadinata, N. S. (2008). Metode Penelitian Pendidikan. Bandung: Program Pascasarjana Universitas Pendidikan Indonesia Dengan PT Remaja Rosdakarya. 